\title{
Technological features of thick-film electric heating elements
}

\author{
Ye.Ya. Telnikov, O.M. Nedbailo (0000-0003-1416-9651), O.G. Chernyshyn (0000-0001-7702-894X) \\ The State Enterprise "Engineering Center «Drying»” Institute of Engineering Thermophysics of NAS of Ukraine, \\ str. Bulakhovskogo, 2, Bldg. 2, Kyiv, 03164, Ukraine \\ Tel.: +380444240279, tel./fax +380444243283 \\ E-mail:icsushka@gmail.com
}

Article info: received 18.02.2020, revised 02.03.2020, accepted 27.03.2020

Telnikov, Ye.Ya., Nedbailo, O.M., Chernyshyn, O.G. (2020) Technological features of thick-film electric heating elements 1(46), DOI: 10.26909/csl.1.2020.2

The article deals with the technical parameters of thick-film heating elements, the peculiarities of their operation, as well as the scope of use in household and industrial heat-generating electrical devices.

The world is constantly researching the possibility of developing heating elements without the aforementioned disadvantages of tube thermal elements, which allow more efficient use of consumed electricity, which leads to significant savings. A new type of heat to heat converter is proposed in this direction. The use of this converter - the heating element - in various industrial and household products can save up to $30 \%$ of electricity consumption.

At the heart of the design of the heating element is a developed system of different properties of composite nanostructured materials - pastes. On the basis of this system of materials the technology of production of new heating elements with unique properties was created. The heating element is made by screen printing (silk screening) of special composite materials on a dielectric or metal substrate with their subsequent heat treatment. Dielectric, resistive, dielectric layers are sequentially applied to a flat substrate of any configuration, but can also be applied to cylindrical surfaces.

Purposeful formation of a conductive structure in the resistive layers of thick-film heating elements and the ability to influence the properties of the nanoscale layer between the particles of the conductive phase allowed to create a group of materials, and on their basis, a series of heating elements with the properties of the technical intellect, environment. The technology for production of heating elements with self-regulation of parameters for wide values of supply voltage, thermal power, and specific heat dissipation power (surface heat flux density) has been developed.

One of the significant advantages of the technology is the absence in the resistive paste of expensive and scarce precious metals and their compounds, which are part of similar pastes, offered by leading manufacturers in the world. Due to this, the cost of manufacturing such pastes is substantially lower than that of the world.

Key words: metal-ceramic compositions, thick-film heating elements, nanostructured materials, pastes.

\section{Технологічні особливості товстоплівкових електронагрівальних елементів}

\author{
Е.Я. Тельников, О.М. Недбайло, О.Г. Чернишин
}

Державне підприсмство «Інженерний цеентр «Сушка»» Інституту технічної теплофізики НАН України, Київ, Украӥна

У статті розглядаються технічні параметри товстоплівкових нагрівальних елементів, особливості їхньої експлуатації, а також сфера використання в побутових і промислових тепловиділяючих електричних пристроях.

Вступ

Одним з головних елементів теплових приладів $\epsilon$ нагрівальний елемент. У промисловій та побутовій техніці використовується безліч різновидів трубчастих електронагрівачів (ТЕНів). В основі їх конструкцій використовуються дроти 3 високим електричним опором і температурою плавлення (вольфрам, ніхром і інші сплави), що запресовані в діелектричному шарі і вставлені в металеву трубку. Дана конструкція нагрівального елементу має низку істотних недоліків: 
- погана теплопровідність від нагрівального дроту до поверхні ТЕНу, що веде до перегрівання дроту, що пришвидшує його зношеність;

- недостатня захищеність дроту від контакту з повітрям, що веде до його окислення і можливого передчасного виходу з ладу;

- невисока питома поверхнева потужність розсіювання теплоти.

Однак високий ступінь електробезпеки і можливість виготовлення гнучких трубок різних конфігурацій забезпечили ТЕНам різнобічне застосування в промисловості і побутовій техніці для перетворення електричної енергії в теплоту.

У світі постійно проводяться наукові дослідження щодо можливості розроблення нагрівальних елементів без вищезазначених недоліків ТЕНів, що дозволяють більш ефективно використовувати споживану електроенергію, що призводить до суттєвої iii економії. У цьому напрямку пропонується новий тип перетворювача електричної енергії в теплоту. Використання даного перетворювача - нагрівального елемента - в різних промислових і побутових виробах дозволяє економити споживання електроенергії до $30 \%$.

\section{Матеріали та методи досліджень}

В основі конструкції нагрівального елементу лежить розроблена система різних за своїми властивостями композиційних наноструктурних матеріалів - паст. На основі цієї системи матеріалів створена технологія виробництва нових нагрівальних елементів 3 унікальними властивостями. Нагрівальний елемент виготовляється методом трафаретного друку (шовкографія) спеціальних композиційних матеріалів на діелектричну або металеву підкладку iз подальшою їх термообробкою. Діелектричний, резистивний, діелектричний шари послідовно наносяться на плоску підкладку будь-якої конфігурації, але можуть наноситись також і на циліндричні поверхні.

При виготовленні нагрівального елементу (НЕ) використовуються 4 типи порошкових композицій у вигляді паст:

1. Діелектрична №1 - створює діелектричний шар на металевій підкладці з жаростійкої стали. Шар товщиною 150 мкм витримує на пробій не менше 2500 В прикладеної різниці потенціалів.

2.Діелектрична №2 - для формування захисного шару на резистивних доріжках. Вона ізолює матеріал резистивного шару від взаємодії з киснем повітря та іншими інгредієнтами навколишнього середовища при робочих режимах, що збільшує довговічність експлуатації НЕ в десятки разів у порівнянні з традиційними ТЕНами.
3. Резистивна - основний матеріал у виробництві товстоплівкових нагрівальних елементів, що представляє собою суміш порошків різних за властивостями інгредієнтів, диспергованих в органічному сполучному. Змінюючи співвідношення і склад інгредієнтів в пасті вдається отримати набір композиційних матеріалів із необхідним комплексом параметрів. Матеріалами струмопровідної фази резистивних паст є бориди перехідних, лужно- і рідкоземельних металів

4. Контактна - низькоомна струмопровідна композиція для закріплення струмопідводів до резистивного шару. Матеріал контактної пасти тринікеля борід.

Одним 3 істотних переваг технології є відсутність в композиційних резистивних пастах дорогих і дефіцитних дорогоцінних металів та їх сполук, що входять в склади аналогічних паст, запропонованих провідними виробниками в світі. Завдяки цьому собівартість виготовлення таких паст істотно нижче світових аналогів [1].

На основі цієї системи матеріалів створена технологія виробництва нових нагрівальних елементів iз наступними властивостями:

- підкладки нагрівачів - метал (сталь типу AISI430, аналог 12X17), кераміка типу ВК94;

- композиційні пасти - ТУ У 24.7-14307699-0012003 (діелектрична, резистивна, контактна);

- можливі габаритні розміри нагрівачів (обмежені наявним обладнанням):

- довжина 1 - 500 мм;

- ширина 1 - 300 мм;

- товщина 0,5 - 8 мм;

- циліндр Ø2 - 50 мм (довжина 10 - 450 мм).

- напруга живлення - 1,5 В - 720 В постійного або змінного струму;

- питомий поверхневий опір резистивного шару 0,05 - 50 Ом/квадрат;

- зміна опору в процесі експлуатації за 10000 годин - не більше $2 \%$;

- пробивна напруга діелектричних шарів - не менше $2500 \mathrm{~B}$;

- максимальна питома поверхнева потужність розсіювання - до $50 \mathrm{BT} / \mathrm{cm}^{2}$;

- максимальна робоча температура $-650^{\circ} \mathrm{C}$.

Основними перевагами нагрівачів $€$ знижене енергоспоживання, підвищена надійність та спрямованість теплового потоку. Такі нагрівачі представляють собою металеву 3 діелектричним покриттям підкладку товщиною $1 \ldots 8$ мм практично будь-якої геометричної конфігурації (рис. 1). На підкладці друкарським способом наноситься малюнок (також будь-якої конфігурації) резистивною струмопровідною пастою, що представляє собою розвинений контур електричного кола опору, що 


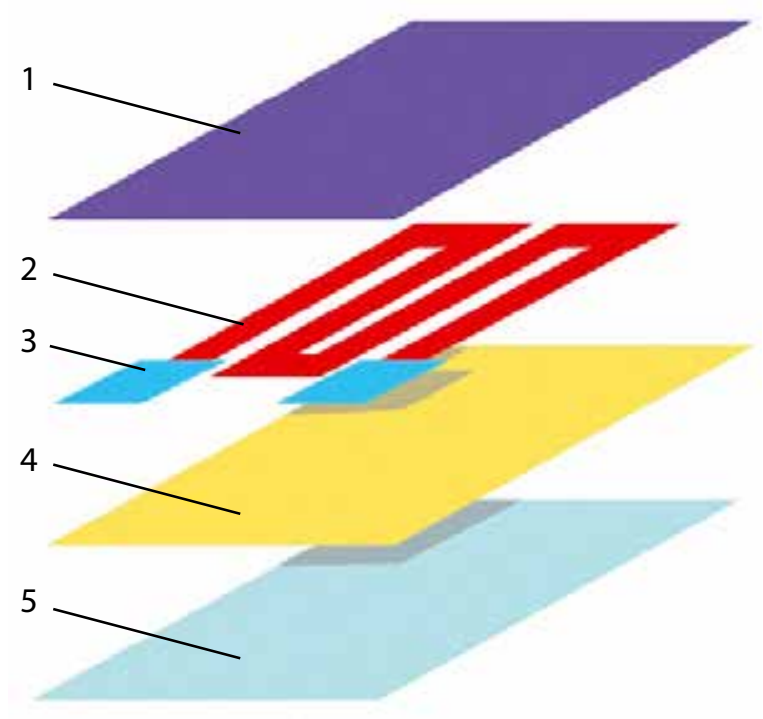

Рис. 1. Конструкція товстоплівкового нагрівального елемента

1 - захисний діелектричний шар;

2 - резистивний шар у вигляді плівкової доріжки; 3 - контактна паста; 4 - діелектричний шар;

5 - сталева або керамічна підкладка

надійно ізольований як від основи, так і від зовнішнього середовища.

Для виготовлення нагрівальних елементів (рис. 2) використовується комплект сумісних струмопровідних (ПК), резистивних (ПРН) і діелектричних (ПД) паст. Пасти ПД використовуються для виготовлення склоподібних покриттів (емалей) на металевих підкладках або захисних діелектричних покриттях на електропровідних шарах.

Пасти ПРН використовуються для виготовлення резистивного шару нагрівальних елементів.

Пасти ПК використовуються для приєднання дротових або стрічкових контактів, а також пластин

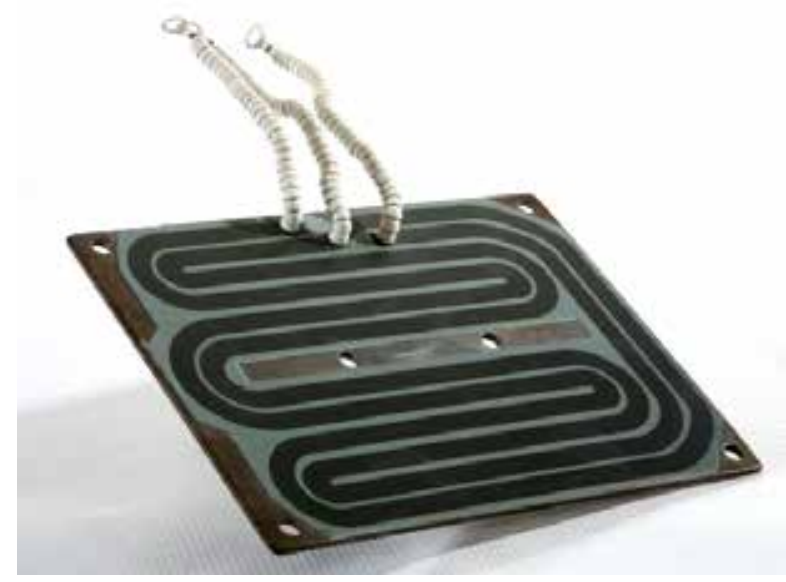

Рис. 2. Фото типового нагрівального елементу або шайб із латуні до контактних площадок нагрівальних елементів на підкладках з кераміки та металу.

Температура формування всіх шарів нагрівального елементу складає понад $800{ }^{\circ} \mathrm{C}$. Термообробка проводиться в повітрі. Для додавання порошковим композиціям друкарських властивостей до їхнього складу вводиться органічна рідка сполука, що повністю видаляється в процесі термообробки.

В якості підкладок для нанесення шарів можуть використовуватися жароміцні стали типу AISI - 409, AISI - 430, кераміка (оксидна і безоксидна), склокераміка, фарфор, скло і ряд інших діелектричних матеріалів. Загальна товщина сформованих шарів HЕ не перевищує 250 мкм.

У процесі термообробки нанесених на підкладку резистивних матеріалів відбувається:

- перша стадія - організація струмопровідної структури в процесі видалення органічного наповнювача;

- друга стадія - визначає положення кожної частинки в шарі. При цьому відбувається плавлення скла. Зі збільшенням температури випалу в'язкість скла зменшується. Відбувається процес формування струмопровідної структури;

- третя стадія - стадія фіксування - утворення струмопровідної структури в процесі кристалізації скла;

- четверта стадія - визначає адгезію до підкладки i цілісність резистивного шару. Відбувається охолодження шару.

Управління властивостями резистивних шарів здійснюється наступним чином (основні прийоми):

- використання струмопровідної фази із відмінними електрофізичними властивостями;

- зміна співвідношення кількості скла і струмопровідної фази в композиціях;

- застосування порошків скла і фази різної дисперсності;

- варіювання температурно-часовим режимом термообробки (у визначеному діапазоні, що задається властивостями скла);

- використання легуючих добавок, що здійснюють вплив на фізико-хімічні процеси під час термообробки.

\section{Результати та їх обговорення}

Кінцевою метою $є$ отримання резистивної плівки завтовшки $10 \div 100$ мкм, в скляній матриці якої певним чином розташовані частинки струмопровідної фази.

Вони можуть:

- бути майже дотичні одна одній;

- вистроюватись в ланцюжки; 
- утворювати конгломерати із дрібних частинок струмопровідної фази;

- розташовуватись майже рівномірно по всьому об'єму шару.

Можливе поєднання декількох структур в одному зразку.

Приклади можливих структур резистивних плівок показані на рис. 3 (фото $з$ оптичного мікроскопу Neofot-2 x1000).
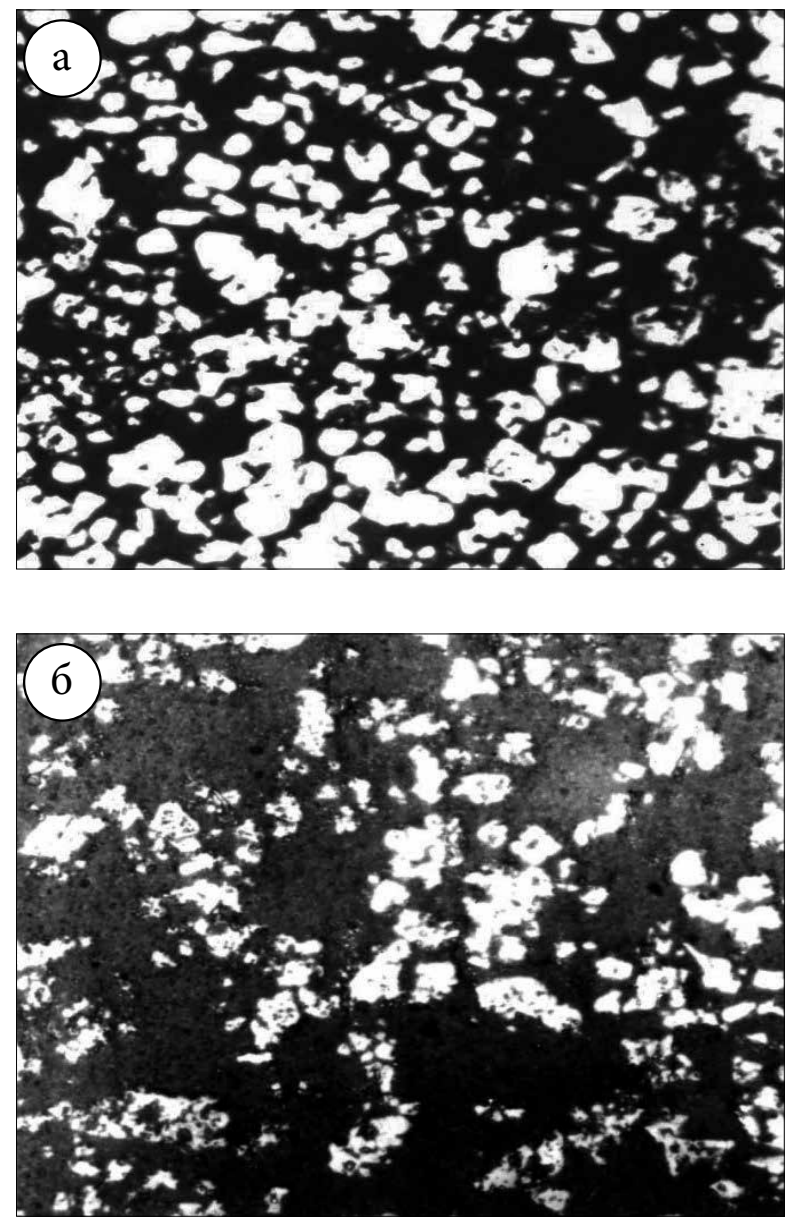

Рис. 3. Композиція структур резистивних плівок: а) 340 мас. \% скла; б) 360 мас. \% скла

При цьому резистивний шар представляє собою складну гетерогенну неупорядковану систему, що містить області з металевим характером провідності і діелектричні ділянки. Електропровідність в таких системах є суперпозицією металевого типу в провідній фазі і активаційного через прошарок поміж частинками.

Залежно від складу, об'ємної частки компонентів, режиму термообробки в структурі плівки переважають або безперервні ланцюги провідних частинок із щільними контактами, або ланцюги 3 частинок, розділених діелектричними прошарками.
У другому випадку, електричні властивості плівок визначаються домінуючим механізмом перенесення заряду крізь утворені прошарки зі скла і оксидних плівок із частинками струмопровідної фази. Для середньо і високоомних плівок основними механізмами перенесення заряду крізь прошарок є стрибковий або стрибково - пастковий, а для низькоомних переважає тунелювання (в тому числі резонансне).

Теоретичний розрахунок показав, що величина середньої товщини прошарка поміж частинками струмовпровідної фази в шарі, що визначена в широкому інтервалі значень електричного опору плівок, може становити величину в межах $2 \div 150$ мкм.

При цьому склад і властивості прошарку формуються в процесі взаємодії розплавленого скла iз оксидними плівками частинок струмопровідної фази і легування композицій.

Змінюючи як відстані між частинками струмопровідної фази, так і склад прошарку, вдається регулювати, в певних межах, величину питомого електричного опору резистивних плівок і значення температурного коефіцієнта електроопору (ТКО).

Основними фізичними параметрами, що визначають форму потенційного бар'єра в процесі електропереносу і його властивості, $\epsilon$ значення роботи виходу провідника (струмопровідної фази), діелектрика (прошарку) і величина електронної спорідненості в склі.

У розглянутих низькоомних композиціях, на основі яких виготовляються НЕ, електроперенос через прошарок здійснюється за допомогою носіїв, що інжектовані з струмопровідної фази.

У низькоомних композиціях має місце велика різниця потенціалів і мала товщина прошарку, що забезпечує інжекцію носіїв до зони струмопровідності. При цьому ТКО позитивний і наближений до значення ТКО матеріалу струмопровідної фази.

Підтвердженням основного впливу властивостей матеріалу струмопровідної фази на параметри низькоомних резистивних плівок на їх основі служать їхні близькі значення ТКО, коефіцієнтів Холла і термоелектрорушійної сили. Це пояснюється наявністю зонних містків між частинками. Відповідний електричний зв'язок між частинками обумовлює переважання індуктивного опору над ємнісним в області високих частот.

Низькоомні резистивні композиції дозволили створити нагрівальні елементи 3 металевим типом провідності і позитивним ТКО, близьким до такого у металоподібної струмопровідної фази i, як наслідок, чутливих до змін навколишнього середовища.

Зі збільшенням температури електроопір НЕ збільшується (рис. 4), що призводить до зменшення струму і споживаної енергії [2]. 


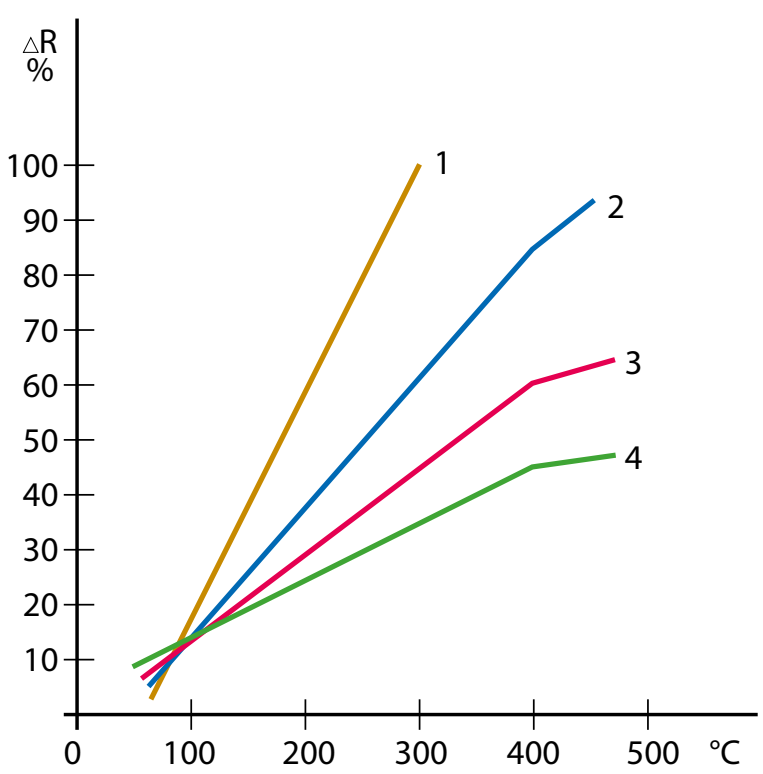

Рис. 4. Зміна опору розроблених резистивних паст в залежності від температури:

$1-0,1$ Ом/кв; 2 - 0,2 Ом/кв; 3 - 1,0 Ом/кв; $4-2,0 \mathrm{Oм} / \mathrm{\kappa в}$

У разі зменшення температури НЕ завдяки контакту із теплоприймачем його опір зменшиться, а електрична потужність зростатиме, поки не встановиться тепловий баланс поміж ними. При створенні НЕ враховуються умови експлуатації та особливості конструкції, що дозволяє уникнути його руйнування до встановлення балансу, особливо в умовах відсутності тепловідведення.

У плоских нагрівальних елементів, на відміну від ТЕНів, 99 \% теплоти розподіляється тільки в двох напрямках. Таким чином, площина елемента, що передає теплоту в напрямку робочої поверхні, збільшується в десятки разів. При цьому тепловим бар'єром є діелектричний прошарок між резистивним матеріалом і робочою поверхнею, що у НЕ на порядок менший за такий у більшості конструкцій ТЕНів (товщина діелектричного шару на металевій підкладці не більше 250 мкм, у ТЕНів вона складає від 3 мм).

У конструкціях з НЕ, використовуючи теплоізоляційний матеріал або відбивну поверхню з боку резистивного шару, вдається спрямувати тепловий потік з протилежного боку на робочу поверхню нагрівача.

Таким чином, більш ефективне використання теплоти призводить до можливості створення теплотехнічних виробів із такими ж експлуатаційними характеристиками, що і у конструкціях на основі ТЕНів, але при меншому питомому споживанні електричної енергії.

\section{Висновки}

Цілеспрямоване формування струмопровідної структури в резистивних шарах товстоплівкових нагрівальних елементів і можливість впливати на властивості нанорозмірного прошарку між частинками струмопровідної фази дозволило створити групу матеріалів, та на їхній основі, серії нагрівальних елементів із властивостями технічного інтелекту, тобто самостійною зміною параметрів нагрівального елементу у відповідності до параметрів навколишнього середовища. Розроблено технологію для виготовлення нагрівальних елементів із саморегулюванням параметрів для значень напруги живлення від 1,5 до $750 \mathrm{~B}$, тепловою потужністю від декількох Ват до 10 кВт та питомою потужністю розсіювання теплоти (поверхневою густиною теплового потоку) до 50 $\mathrm{BT} / \mathrm{cm}^{2}$.

Особливості конструкції НЕ і малі зайві втрати теплоти при теплопередачі в теплотехнічних виробах дозволяє знизити споживання електроенергії в цілому до $30 \%$.

\section{References}

1. Тельников, Е.Я., Хмара, И.А., Чернылиин, А.Г., Недбайло, А.Н. Исследование электрофизических свойств толстопленочных электродов на пьезокерамике в особых условиях. Кераміка: наука і життя. - 2019. - №1 (42). - С. 26 - 31. DOI: 10.26909/ csl.2.2019.4.

2. Тельников, Е.Я., Чернылиин, А.Г., Недбайло, А.Н., Хмара, И.А. Структура и механизм электропроводности резистивных композиций для толстопленочных металлокерамических нагревательных элементов. Кераміка: наука і життя. - 2019. - №2 (43). C. 14 - 18. DOI: $10.26909 / \mathrm{csl} .2 .2019 .4$. 